\title{
Nutritive and Antioxidant properties of Shade Dried Leafy Vegetables Consumed in Northern Côte d'Ivoire
}

\author{
Patricia Dehegnan Oulaï, Lessoy Thierry Zoué*, Sébastien Lamine Niamké
}

Biotechnology Laboratory, Biosciences Department, Felix Houphouet-Boigny University, 22 BP 582 Abidjan 22, Côte d'Ivoire (Ivory Coast) A R T I C L E I N F O

Article history:

Received 04 October 2015

Accepted 22 December 2015

Available online, ISSN: 2148-127X

Keywords:

Food preservation

Leafy vegetables

Nutritive composition

Shadow drying

A B S T R A C T

Leafy vegetables are highly perishable and often subjected to post-harvest wastes. Among the various methods of preservation, the effect of shadow drying on the nutritive value and antioxidant properties of five (5) leafy vegetables species widely consumed in Northern Côte d'Ivoire was investigated. These species were Amaranthus hybridus, Andasonia digitata, Ceiba patendra, Hibiscus sabdariffa and Vigna unguiculata. Experiment was conducted as follow: portions of washed and drained fresh leafy vegetables $(500 \mathrm{~g})$ were spread on clean filter paper and kept in a well-ventilated room of the laboratory at $25^{\circ} \mathrm{C}$ for 5,10 and 15 days. The results of proximate composition after 15 days of shadow drying were: moisture (15.19-20.36\%), ash (9.14 -19.54\%), crude fiber $(11.04-27.40 \%)$, proteins $(11.14-17.94 \%)$, lipids $(2.41-5.86 \%)$ and carbohydrates $(16.59-45.14 \%)$. The concentration of minerals increased with respective values after 15 days of shadow drying: calcium $(68.14-408.09 \mathrm{mg} / 100 \mathrm{~g})$, magnesium $(50.62-317.23 \mathrm{mg} / 100 \mathrm{~g})$, iron $(27.52-92.03 \mathrm{mg} / 100 \mathrm{~g})$ and zinc $(10.17-16.73 \mathrm{mg} / 100 \mathrm{~g})$. During shadow drying, vitamin $\mathrm{C}$ and carotenoids were subjected to losses estimated to $35.52-70.50 \%$ and $22.82-45.63 \%$, respectively. Contrary to these losses, antioxidant activity increased and ranged from 57.45 to $75.55 \%$ after 15 days of shadow drying. All these results suggest that the considerable nutrient contents of shade dried leafy vegetables make them good source of food supplements in order to meet the nutritional requirements of Ivorian population.
"Corresponding Author:

E-mail: y.lessoy@yahoo.fr postharvest handling at the room temperature (Kyureghian et al., 2010). The very short shelf life of leafy vegetables is mainly related to their high respiratory activity and this seasonality of leafy vegetables constitutes a major constraint to their utilization during the dry season (Oguche, 2011). To extend the period during which they are available, the most common method used is the natural air- drying which depends on many factors such as air temperature, relative humidity, air velocity and initial moisture content of the product (Subhash and Neeha, 2014). According to Kolawole et al (2010), drying removes the moisture from the food so bacteria, yeast and molds cannot grow on and spoil. Apart from moisture losses, the changes in organoleptic quality of dried leafy vegetables are optical properties (colour, appearance), sensory properties (odour, taste, flavour), and structural properties (density, porosity, specific volume, textural properties) (Jokic et al., 2009). Dried leafy vegetables are generally tasty, nutritious, lightweight, easy-to prepare, and easy-to-store and use. The energy input is less than what is needed to freeze or can, and the storage space is minimal compared with that needed for canning jars and freezer containers (Medeiros and Ramlay, 2009). 
In rural areas of Northern Côte d'Ivoire (Ivory Coast) were population are not provided by refrigerator, shadow drying is the method often used for the preservation of leafy vegetables before their consumption through recipes made of sauces and starchy staples foods. Five (5) leafy vegetables species (Amaranthus hybridus "boronbrou", Andasonia digitata "baobab", Ceiba patendra "fromager", Hibiscus sabdariffa "dah" and Vigna unguiculata "haricot") mostly consumed in Northern Côte d'Ivoire are subjected to this traditional drying method. Earlier reports have highlighted the nutritive potential of these fresh leafy vegetables (Oulai et al., 2014) and the present study aims to determine the effect of shadow drying method on their nutritive and antioxidant properties.

\section{Material and Methods}

\section{Material}

Leafy vegetables (Amaranthus hybridus, Andasonia digitata, Ceiba patendra, Hibiscus sabdariffa and Vigna unguiculata) were collected fresh and at maturity from cultivated farmlands located at Dabou (latitude: $5^{\circ} 19^{\prime} 14^{\prime \prime}$ North; longitude: 4²2'59"West) (Abidjan District, Côte d'Ivoire). Samples were harvested at the early stage (between one and two weeks of the appearance of the leaves). These plants were previously authenticated by the National Floristic Center (University Felix HouphouëtBoigny, Abidjan-Côte d'Ivoire).

\section{Drying Processing}

The collected leafy vegetables were rinsed with deionized water and the edible portions were separated from the inedible portions. The edible portions were allowed to drain at ambient temperature and separated into two portions of $500 \mathrm{~g}$ each. The first portion was spread on clean filter paper and kept in a well-ventilated room of the laboratory at $25^{\circ} \mathrm{C}$ for 5,10 and 15 days. Natural current of air was used for shadow drying and the leaves were constantly turned to avert fungal growth (Vanderhulst, 1990). The second $500 \mathrm{~g}$ portion of leafy vegetables was not subjected to any form of drying and used as the control (raw). After drying period, the dried leaves were stored in air-tight containers for further analysis.

\section{Nutritive Analyses}

Physicochemical analysis: Proximate analysis was performed using official methods (AOAC, 1990). The moisture content was determined by the difference of weight before and after drying samples $(10 \mathrm{~g})$ in an oven (Memmert, Germany) at $105^{\circ} \mathrm{C}$ until constant weight. Ash fraction was determined by the incineration of dry matter sample (5 g) in a muffle furnace (Pyrolabo, France) at $550^{\circ} \mathrm{C}$ for $12 \mathrm{~h}$. The percentage residue weight was expressed as ash content. For crude fiber, $2 \mathrm{~g}$ of dry matter sample were weighed into separate $500 \mathrm{~mL}$ round bottom flasks and $100 \mathrm{~mL}$ of $0.25 \mathrm{M}$ sulphuric acid solution was added. The mixture obtained was boiled under reflux for $30 \mathrm{~min}$. Thereafter, $100 \mathrm{~mL}$ of $0.3 \mathrm{M}$ sodium hydroxide solution was added and the mixture were boiled again under reflux for $30 \mathrm{~min}$ and filtered through Whatman paper. The insoluble residue was then incinerated, and weighed for the determination of crude fiber content. Proteins were determined through the Kjeldhal method and the lipid content was determined by Soxhlet extraction using hexane as solvent. Carbohydrates content and calorific value were calculated and expressed on dry matter basis using the following formulas (FAO, 2002):

$$
\begin{aligned}
& \text { Carbohydrates: } 100-(\% \mathrm{M}+\% \mathrm{P}+\% \mathrm{~L}+\% \mathrm{~A}+\% \mathrm{~F}) \\
& \text { Where; }
\end{aligned}
$$

$$
\begin{array}{ll}
\mathrm{M} & : \text { moisture } \\
\mathrm{P} & : \text { proteins } \\
\mathrm{L} & : \text { lipids } \\
\mathrm{A} & : \text { ash } \\
\mathrm{F} & : \text { fibres }
\end{array}
$$

Calorific value: $(\% \mathrm{Px} 2.44)+(\% \mathrm{Cx} 3.57)+(\% \mathrm{Lx} 8.37)$

Where;

$$
\begin{array}{ll}
\mathrm{P} & \text { : proteins } \\
\mathrm{C} & \text { : carbohydrates } \\
\mathrm{L} & \text { : lipids }
\end{array}
$$

Mineral analysis: Minerals contents were determined by the ICP-MS (inductively coupled argon plasma mass spectrometer) method (CEAEQ, 2013). The crushed dried samples $(5 \mathrm{~g})$ were burned to ashes in a muffle furnace (Pyrolabo, France). The ashes obtained were dissolved in $10 \mathrm{~mL}$ of $\mathrm{HCl} / \mathrm{HNO}_{3}$ and transferred into $100 \mathrm{~mL}$ flasks and the volume was made up using deionized water. The mineral composition of each sample was determined using an Agilent 7500c argon plasma mass spectrometer. Calibrations were performed using external standards prepared from a $1000 \mathrm{ppm}$ single stock solution made up with $2 \%$ nitric acid.

Oxalates quantification: The titration method as described by Day and Underwood (1986) was performed. One (1) g crushed leaves was weighed into $100 \mathrm{~mL}$ conical flask. A quantity of $75 \mathrm{~mL}$ of sulphuric acid $(3 \mathrm{M}$ ) was added and stirred for $1 \mathrm{~h}$ with a magnetic stirrer. The mixture was filtered and $25 \mathrm{~mL}$ of the filtrate was titrated while hot against $\mathrm{KMnO}_{4}$ solution $(0.05 \mathrm{M})$ to the end point.

Phytates quantification: Phytates contents were determined using the Wade's reagent colorimetric method (Latha and Eskin, 1980). A quantity (1 g) of crushed leaves was mixed with $20 \mathrm{~mL}$ of hydrochloric acid $(0.65$ $\mathrm{N})$ and stirred for $12 \mathrm{~h}$ with a magnetic. The mixture was centrifuged at $12000 \mathrm{rpm}$ for $40 \mathrm{~min}$. An aliquot $(0.5 \mathrm{~mL})$ of supernatant was added with $3 \mathrm{~mL}$ of Wade's reagent. The reaction mixture was incubated for $15 \mathrm{~min}$ and absorbance was measured at $490 \mathrm{~nm}$ by using a spectrophotometer (PG Instruments, England). Phytates content was estimated using a calibration curve of sodium phytate $(10 \mathrm{mg} / \mathrm{mL})$ as standard. 


\section{Antioxidant Properties Evaluation}

Vitamin C content: Vitamin $\mathrm{C}$ was determined by titration using the method described by Pongracz et al. (1971). About $10 \mathrm{~g}$ of crushed leaves were soaked for 10 min in $40 \mathrm{~mL}$ metaphosphoric acid-acetic acid $(2 \%, \mathrm{w} / \mathrm{v})$. The mixture was centrifuged at $3000 \mathrm{rpm}$ for $20 \mathrm{~min}$ and the supernatant obtained was diluted and adjusted with 50 $\mathrm{mL}$ of bi-distilled water. Ten (10) $\mathrm{mL}$ of this mixture was titrated to the end point with dichlorophenol-indophenol (DCPIP) $0.5 \mathrm{~g} / \mathrm{L}$.

Carotenoids content: Carotenoids content was carried out according to Rodriguez-Amaya (2001). Two (2) g of crushed leaves were mixed three times with $50 \mathrm{~mL}$ of acetone until loss of pigmentation. The mixture obtained was filtered and total carotenoids were extracted with 100 $\mathrm{mL}$ of petroleum ether. Absorbance of extracted fraction was then read at $450 \mathrm{~nm}$ by using a spectrophotometer (PG Instruments, England). Total carotenoids content was subsequently estimated using a calibration curve of $\beta$ carotene $(1 \mathrm{mg} / \mathrm{mL})$ as standard.

Polyphenols content: Polyphenols content was determined using the method reported by Singleton et al. (1999). A quantity (1 g) crushed leaves was soaked in 10 $\mathrm{mL}$ of methanol $70 \%(\mathrm{w} / \mathrm{v})$ and centrifuged at $1000 \mathrm{rpm}$ for $10 \mathrm{~min}$. An aliquot $(1 \mathrm{~mL})$ of supernatant was oxidized with $1 \mathrm{~mL}$ of Folin-Ciocalteu's reagent and neutralized by $1 \mathrm{~mL}$ of $20 \%(\mathrm{w} / \mathrm{v})$ sodium carbonate. The reaction mixture was incubated for $30 \mathrm{~min}$ at ambient temperature and absorbance was measured at $745 \mathrm{~nm}$ by using a spectrophotometer (PG Instruments, England). The polyphenols content was obtained using a calibration curve of gallic acid $(1 \mathrm{mg} / \mathrm{mL})$ as standard.

Antioxidant activity: Antioxidant assay was carried out using the 2,2-diphenyl-1-pycrilhydrazyl (DPPH) spectrophotometric method outlined by Choi et al. (2002). About $1 \mathrm{~mL}$ of $0.3 \mathrm{mM}$ DPPH solution in ethanol was added to $2.5 \mathrm{~mL}$ of sample solution ( $1 \mathrm{~g}$ of crushed leaves was mixed in $10 \mathrm{~mL}$ of methanol, filtered through filter paper and was allowed to react for $30 \mathrm{~min}$ at room temperature). Absorbance values were measured with a spectrophotometer (PG Instruments, England) set at 415 $\mathrm{nm}$. The average absorbance values were converted to percentage antioxidant activity using the following formula:

\section{Antioxidant activity $(\%)=100-[(\mathrm{AS}-\mathrm{AB}) \times 100 / \mathrm{APC}]$}

Where;

AS : Abs of sample

$\mathrm{AB}$ : Abs of blank

APC : Abs positive control

\section{Statistics}

All the analyses were performed in triplicate and data were analyzed using EXCELL and STATISTICA 7.1 (StatSoft). Differences between means were evaluated by Duncan's test. Statistical significant difference was stated at $\mathrm{P}<0.05$

\section{Results and Discussion}

Nutritive value

Table 1 shows the proximate composition of fresh and shade dried leafy vegetables. Moisture content was significantly $(\mathrm{P}<0.05)$ higher $(70.45-86.05 \%)$ for fresh vegetables than that $(15.19-20.36 \%)$ of dried ones after 15 days of shadow drying. The high moisture content in the fresh leafy vegetables is expected since it has been reported that vegetables in their fresh state contain basically $85 \%$ water (Fakeye, 2009). The maximum moisture content varies between individual leafy vegetables because of structural differences and cultivation conditions (Florkowski et al., 2009). High moisture content in leafy vegetables is also indicative of their freshness as well as easy perish-ability (Adepoju and Oyediran, 2008). Indeed, higher moisture content of leafy vegetables suggests that they will not store for long time without spoilage since higher water activity could enhance microbial activity and food spoilage (Ejoh et al., 2007). The lower moisture content of shade dried leafy vegetables is not surprising since Dupriez and Coener (1992) reported that drying involves lowering the amount of water to below $1-55 \%$ in vegetables. Moisture content of food is very important for shelf-life and any food prepared from dried leafy vegetables has more keeping quality than the fresh one (Chou and Chua, 2001). Indeed, vegetable crops, with high moisture content will favor the growth of microorganisms and promote enzymatic reactions which increase their perishability (Kolawole et al. 2010). Therefore, the drying processing of the studied leafy vegetables could avoid wastage and the dried leaves could be easily converted in to fresh-like form by rehydrating and this technique facilitates the utilization of dried leaves in other parts of the country where this vegetable is unavailable in plenty.

Generally the removal of moisture, according to Morris et al. (2004) leads to an increase in concentration of nutrients as indicated after 15 days of shadow drying with regard to the contents of ash, crude fiber, proteins, lipids and carbohydrates (Table 1). The ash contents (9.14 $-19.54 \%$ ) of shadow dried samples were similar to that reported by Onwuka et al. (2002) for tomatoes, okra, pepper and onions subjected to the same preservation treatment. Ash content indicates the mineral content of food substances and shade dried leafy vegetables could be considered as valuable sources of minerals for alleviating micronutrient deficiency related to minerals in human nutrition. Crude fiber contents were significantly higher $(\mathrm{P}<0.05)$ for 15 days shade dried leaves $(11.04-27.40 \%)$ than those $(1.99-9.30 \%)$ of fresh leafy vegetables. Dietary fiber may be classified into three major groups (cellulose, non-cellulose and lignin) according to their structure and properties. Foods containing high amount of dietary fiber are very low in caloric content, thus high fiber diets as dried leafy vegetables could be recommended for weight reducing regimes (Komal and Kaur, 1992). Dietary fiber in vegetables reduces food transit time in the alimentary canal and the incidence of constipation and other related diseases (Ifon et al., 2009). 
Table 1 Proximate composition of shade dried leafy vegetables consumed in Northern Côte d'Ivoire

\begin{tabular}{|c|c|c|c|c|c|c|c|}
\hline $\begin{array}{l}\text { Leafy } \\
\text { vegetables }\end{array}$ & $\begin{array}{c}\text { Moisture } \\
(\%)\end{array}$ & $\begin{array}{l}\text { Ash } \\
(\%) \\
\end{array}$ & $\begin{array}{c}\text { Crude fiber } \\
(\%)\end{array}$ & $\begin{array}{c}\text { Proteins } \\
(\%)\end{array}$ & $\begin{array}{c}\text { Lipids } \\
(\%)\end{array}$ & $\begin{array}{c}\text { Carbohydrates } \\
(\%)\end{array}$ & $\begin{array}{c}\text { Energy } \\
\text { (Kcal/100g) }\end{array}$ \\
\hline \multicolumn{8}{|c|}{ H. sabdariffa } \\
\hline Raw & $86.05 \pm 1.35^{\mathrm{a}}$ & $1.44 \pm 0.01^{\mathrm{d}}$ & $1.99 \pm 0.24^{\mathrm{d}}$ & $2.02 \pm 0.01^{\mathrm{d}}$ & $0.66 \pm 0.02^{\mathrm{d}}$ & $7.86 \pm 0.25^{\mathrm{d}}$ & $38.54 \pm 0.08^{\mathrm{d}}$ \\
\hline 5 days & $68.50 \pm 0.70^{\mathrm{b}}$ & $3.27 \pm 0.90^{\mathrm{c}}$ & $4.51 \pm 0.11^{\mathrm{c}}$ & $4.58 \pm 0.01^{\mathrm{c}}$ & $1.57 \pm 0.04^{\mathrm{c}}$ & $17.53 \pm 0.84^{\mathrm{c}}$ & $87.21 \pm 2.60^{c}$ \\
\hline 10 days & $38.23 \pm 4.18^{c}$ & $6.50 \pm 0.46^{\mathrm{b}}$ & $8.86 \pm 1.75^{\mathrm{b}}$ & $9.02 \pm 0.00^{\mathrm{b}}$ & $2.61 \pm 0.03^{b}$ & $33.78 \pm 1.32^{b}$ & $172.79 \pm 4.41^{b}$ \\
\hline 15 days & $15.74 \pm 1.91^{\mathrm{d}}$ & $9.14 \pm 0.29^{\mathrm{a}}$ & $12.43 \pm 2.68^{\mathrm{a}}$ & $12.54 \pm 0.05^{\mathrm{a}}$ & $3.42 \pm 0.12^{\mathrm{a}}$ & $45.14 \pm 2.47^{\mathrm{a}}$ & $233.71 \pm 8.40^{\mathrm{a}}$ \\
\hline \multicolumn{8}{|c|}{ A. hybridus } \\
\hline Raw & $72.98 \pm 0.16^{\mathrm{a}}$ & $2.32 \pm 0.36^{\mathrm{c}}$ & $4.82 \pm 0.08^{\mathrm{c}}$ & $3.59 \pm 0.03^{\mathrm{d}}$ & $0.58 \pm 0.00^{\mathrm{d}}$ & $15.76 \pm 0.48^{\mathrm{d}}$ & $82.61 \pm 2.09^{c}$ \\
\hline 5 days & $69.30 \pm 3.11^{\mathrm{b}}$ & $2.66 \pm 0.05^{\mathrm{c}}$ & $5.83 \pm 1.09^{c}$ & $4.20 \pm 0.01^{\mathrm{c}}$ & $0.86 \pm 0.02^{\mathrm{c}}$ & $17.15 \pm 1.07^{\mathrm{c}}$ & $78.62 \pm 3.65^{\mathrm{d}}$ \\
\hline 10 days & $37.07 \pm 2.07^{\mathrm{c}}$ & $5.69 \pm 0.43^{\mathrm{b}}$ & $12.16 \pm 2.45^{\mathrm{b}}$ & $8.67 \pm 0.01^{b}$ & $1.84 \pm 0.02^{\mathrm{b}}$ & $34.57 \pm 2.85^{\mathrm{b}}$ & $159.97 \pm 1.35^{\mathrm{b}}$ \\
\hline 15 days & $20.11 \pm 0.99^{\mathrm{d}}$ & $10.29 \pm 1.15^{\mathrm{a}}$ & $15.52 \pm 0.56^{\mathrm{a}}$ & $11.14 \pm 0.02^{\mathrm{a}}$ & $2.42 \pm 0.12^{\mathrm{a}}$ & $40.51 \pm 0.43^{\mathrm{a}}$ & $192.07 \pm 2.65^{\mathrm{a}}$ \\
\hline \multicolumn{8}{|l|}{ A. digitata } \\
\hline Raw & $77.63 \pm 0.15^{\mathrm{a}}$ & $2.45 \pm 0.09^{\mathrm{d}}$ & $2.81 \pm 0.10^{\mathrm{d}}$ & $4.04 \pm 0.02^{\mathrm{d}}$ & $0.49 \pm 0.00^{\mathrm{d}}$ & $12.58 \pm 0.28^{\mathrm{d}}$ & $59.73 \pm 0.89^{\mathrm{d}}$ \\
\hline 5 days & $70.95 \pm 5.13^{b}$ & $3.22 \pm 0.02^{\mathrm{c}}$ & $3.73 \pm 0.51^{\mathrm{c}}$ & $5.34 \pm 0.00^{\mathrm{c}}$ & $29 \pm 0.00^{c}$ & $15.47 \pm 0.53^{c}$ & $79.03 \pm 1.88^{c}$ \\
\hline 10 days & $39.17 \pm 0.36^{\mathrm{c}}$ & $7.02 \pm 0.07^{\mathrm{b}}$ & $7.88 \pm 0.64^{b}$ & $11.22 \pm 0.00^{\mathrm{b}}$ & $2.84 \pm 0.03^{\mathrm{b}}$ & $31.88 \pm 0.68^{b}$ & $164.95 \pm 2.72^{b}$ \\
\hline 15 days & $15.19 \pm 0.38^{\mathrm{d}}$ & $10.01 \pm 0.35^{\mathrm{a}}$ & $11.04 \pm 2.40^{\mathrm{a}}$ & $12.52 \pm 0.03^{\mathrm{a}}$ & $5.86 \pm 0.02^{\mathrm{a}}$ & $41.97 \pm 2.00^{\mathrm{a}}$ & $237.75 \pm 7.40^{\mathrm{a}}$ \\
\hline \multicolumn{8}{|c|}{ V. unguiculata } \\
\hline Raw & $80.04 \pm 0.56^{\mathrm{a}}$ & $2.23 \pm 0.05^{\mathrm{d}}$ & $3.59 \pm 0.18^{\mathrm{c}}$ & $4.38 \pm 0.06^{\mathrm{d}}$ & $0.84 \pm 0.04^{\mathrm{d}}$ & $8.91 \pm 0.34^{\mathrm{d}}$ & $49.57 \pm 2.06^{\mathrm{d}}$ \\
\hline 5 days & $72.86 \pm 1.22^{\mathrm{b}}$ & $3.04 \pm 0.73^{\mathrm{c}}$ & $4.95 \pm 1.53^{\mathrm{c}}$ & $5.97 \pm 0.03^{c}$ & $1.23 \pm 0.01^{\mathrm{c}}$ & $11.94 \pm 0.79^{\mathrm{c}}$ & $67.51 \pm 2.93^{c}$ \\
\hline 10 days & $45.68 \pm 8.94^{c}$ & $6.20 \pm 0.17^{\mathrm{b}}$ & $10.05 \pm 1.34^{\mathrm{b}}$ & $12.00 \pm 0.03^{b}$ & $2.61 \pm 0.02^{\mathrm{b}}$ & $23.46 \pm 1.17^{b}$ & $134.86 \pm 4.09^{b}$ \\
\hline 15 days & $20.36 \pm 2.77^{\mathrm{d}}$ & $9.52 \pm 0.40^{\mathrm{a}}$ & $15.33 \pm 4.24^{\mathrm{a}}$ & $17.94 \pm 0.00^{\mathrm{a}}$ & $3.92 \pm 0.01^{\mathrm{a}}$ & $32.93 \pm 3.84^{\mathrm{a}}$ & $194.12 \pm 3.60^{\mathrm{a}}$ \\
\hline \multicolumn{8}{|c|}{ C. patendra } \\
\hline Raw & $70.45 \pm 0.52^{\mathrm{a}}$ & $7.58 \pm 0.33^{\mathrm{d}}$ & $9.30 \pm 0.44^{\mathrm{d}}$ & $4.49 \pm 0.00^{\mathrm{d}}$ & $0.41 \pm 0.06^{\mathrm{d}}$ & $7.77 \pm 0.03^{\mathrm{c}}$ & $42.14 \pm 2.29^{\mathrm{d}}$ \\
\hline 5 days & $57.11 \pm 2.17^{\mathrm{b}}$ & $11.14 \pm 0.05^{\mathrm{c}}$ & $13.83 \pm 0.45^{\mathrm{c}}$ & $6.58 \pm 0.00^{\mathrm{c}}$ & $1.29 \pm 0.01^{\mathrm{c}}$ & $10.04 \pm 0.50^{\mathrm{b}}$ & $62.73 \pm 1.82^{\mathrm{c}}$ \\
\hline 10 days & $32.45 \pm 1.51^{\mathrm{c}}$ & $17.66 \pm 0.48^{b}$ & $21.95 \pm 0.95^{\mathrm{b}}$ & $10.71 \pm 0.07^{\mathrm{b}}$ & $2.21 \pm 0.09^{\mathrm{b}}$ & $15.02 \pm 1.30^{\mathrm{a}}$ & $98.22 \pm 5.52^{\mathrm{b}}$ \\
\hline 15 days & $18.19 \pm 2.42^{\mathrm{d}}$ & $19.54 \pm 0.61^{\mathrm{a}}$ & $27.40 \pm 1.73^{\mathrm{a}}$ & $13.31 \pm 0.03^{\mathrm{a}}$ & $2.97 \pm 0.03^{\mathrm{a}}$ & $16.59 \pm 2.29^{\mathrm{a}}$ & $116.55 \pm 8.51^{\mathrm{a}}$ \\
\hline
\end{tabular}

Therefore, adequate intake of the studied dried leafy vegetables could be useful for maintaining bulk, motility and increasing intestinal tract which is also necessary for healthy condition. The protein content s of the 15 days dehydrated leaves was in the range of $11.14-17.94 \mathrm{~g}$ per $100 \mathrm{~g}$. The maximum protein content $(17.94 \%)$ was noted for $V$. unguiculata leaves while the minimum value (11.14\%) was noted for A. hybridus leaves. These protein contents increased by 3 to 5 -fold compared to the fresh samples. Elegbede (1998) observed that increase in protein content of dried leafy vegetables compared to fresh ones may occur as a result of loss of moisture which in turn has an influence on dry matter. These results are also in agreement with the studies done by Lakshmi and Vimla (2000) which showed that dried leaves retained good amounts of protein. Thus, dried leafy vegetables could be good and affordable sources of protein for poor community of developing countries in order to fight against protein deficiency. In addition, it would be interesting to determine the amino acid profile of these leafy vegetables in order to evaluate some essential amino acids contents. The fat content $(2.41-5.86 \%)$ of 15 days dried leaf samples were also higher than their fresh counter parts $(0.41-0.84 \%)$ but leafy vegetables could not be considered as a rich source of fat, which is in agreement with the fact that they are considered as "heart friendly food". Indeed, excess consumption of lipids is mostly involved in cardiovascular diseases. As far as carbohydrate is concerned, leafy vegetables are not considered as a good source of carbohydrate but after 15 days of dehydration, the carbohydrate contents (16.59$45.14 \%$ ) of the leaves were similar to those of vegetables such as potato $(22.6 \%)$ and turnip greens (9.4\%) (Joshi and Mehta, 2010). However, low carbohydrate content of leafy vegetables show that they could supply little or no energy when consumed except when supplemented with other foods (Rossello et al., 2000). Thus, dried leafy vegetables could be used as dietetic foods in human nutrition.

Mineral composition of dehydrated leafy vegetables is given in Table 2.There was a significant $(\mathrm{P}<0.05)$ increase in the mineral content during shadow drying. Levels minerals contents after 15 days of drying were as follow: (68.14-408.09 mg/100 g), magnesium (50.62$317.23 \mathrm{mg} / 100 \mathrm{~g})$, phosphorus $(100.77-271.82 \mathrm{mg} / 100 \mathrm{~g})$, potassium (216.16-759.45 mg/100 g), iron (27.52-92.03 $\mathrm{mg} / 100 \mathrm{~g})$, sodium $(10.81-57.50 \mathrm{mg} / 100 \mathrm{~g})$ and zinc $(10.17-16.73 \mathrm{mg} / 100 \mathrm{~g})$. All the minerals increased manifolds in the dehydrated samples and this fact could be beneficial because micronutrient deficiency also referred as "hidden hunger" is a major problem in the developing countries. With regard to the recommended dietary allowances (RDA) as $\mathrm{mg} /$ day/person for minerals, the level of iron and zinc in the samples could cover RDA and contribute substantially for improving human diet (FAO, 2004). Iron is known to be an essential part of red blood cells (hemoglobin) and enzymes (cytochromes) and consumption of these leafy vegetables could reduce considerably the risk of anaemia (Soetan et al., 2010). The drying processing used in this study increased by 3 to 6 fold the contents of oxalates and phytates compared to the contents of fresh leafy vegetables (Figure 1). Oxalates and phytates are considered as anti-nutritional factors which reduce minerals bioavailability (Hassan et al., 2007). In order to predict the effect of phytates and oxalates contents on nutrients, anti-nutritional factors/minerals ratios were calculated (Table 3). The calculated phytates/calcium ratios of the dried leafy vegetables were below the critical level of 0.5 (Hassan et al., 2007). This implies that phytates contents of the dried leaves would not have deleterious effects on calcium bioavailability for human nutrition. Furthermore, soaking or cooking dried leafy vegetables at household level could reduce the contents of oxalates and phytates. 
Table 2 Mineral composition $(\mathrm{mg} / 100 \mathrm{~g})$ of shade dried leafy vegetables consumed in Northern Côte d'Ivoire

\begin{tabular}{|c|c|c|c|c|c|c|c|}
\hline Leafyvegetables & $\mathrm{Ca}$ & $\mathrm{Mg}$ & $\mathrm{P}$ & $\mathrm{K}$ & $\mathrm{Fe}$ & $\mathrm{Na}$ & $\mathrm{Zn}$ \\
\hline \multicolumn{8}{|l|}{ H. sabdariffa } \\
\hline Raw & $56.22 \pm 0.07^{\mathrm{c}}$ & $41.37 \pm 0.06^{\mathrm{d}}$ & $56.98 \pm 0.00^{\mathrm{d}}$ & $114.10 \pm 0.16^{\mathrm{d}}$ & $14.27 \pm 0.02^{\mathrm{d}}$ & $3.28 \pm 0.00^{\mathrm{d}}$ & $3.64 \pm 0.00^{c}$ \\
\hline 5 days & $57.66 \pm 0.79^{c}$ & $43.68 \pm 0.70^{\mathrm{c}}$ & $87.86 \pm 0.38^{\mathrm{c}}$ & $176.21 \pm 0.22^{\mathrm{c}}$ & $22.10 \pm 0.56^{\mathrm{c}}$ & $8.89 \pm 0.52^{\mathrm{c}}$ & $5.69 \pm 0.13^{\mathrm{b}}$ \\
\hline 10 days & $64.79 \pm 0.17^{\mathrm{b}}$ & $48.33 \pm 0.20^{\mathrm{b}}$ & $102.01 \pm 1.60^{\mathrm{b}}$ & $203.12 \pm 0.38^{b}$ & $25.64 \pm 0.39^{b}$ & $9.29 \pm 0.06^{\mathrm{b}}$ & $17.22 \pm 0.08^{\mathrm{a}}$ \\
\hline 15 days & $68.14 \pm 0.00^{\mathrm{a}}$ & $50.62 \pm 0.00^{\mathrm{a}}$ & $109.55 \pm 1.32^{\mathrm{a}}$ & $216.16 \pm 0.00^{\mathrm{a}}$ & $27.52 \pm 0.00^{\mathrm{a}}$ & $11.93 \pm 0.00^{\mathrm{a}}$ & $17.33 \pm 0.00^{\mathrm{a}}$ \\
\hline \multicolumn{8}{|c|}{ 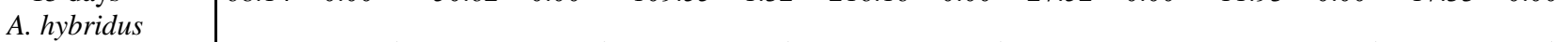 } \\
\hline Raw & $252.45 \pm 0.15^{\mathrm{d}}$ & $134.74 \pm 0.13^{\mathrm{d}}$ & $99.80 \pm 0.00^{\mathrm{d}}$ & $538.51 \pm 0.57^{\mathrm{d}}$ & $21.08 \pm 0.01^{\mathrm{c}}$ & $25.55 \pm 0.01^{\mathrm{d}}$ & $8.59 \pm 0.01^{\mathrm{d}}$ \\
\hline 5 days & $267.86 \pm 1.74^{c}$ & $143.10 \pm 0.95^{c}$ & $106.5 \pm 1.63^{\mathrm{c}}$ & $571.44 \pm 1.46^{\mathrm{c}}$ & $22.59 \pm 0.15^{\mathrm{c}}$ & $28.32 \pm 0.25^{\mathrm{c}}$ & $9.23 \pm 0.08^{\mathrm{c}}$ \\
\hline 10 days & $287.84 \pm 1.42^{b}$ & $164.43 \pm 0.50^{b}$ & $123.08 \pm 2.33^{b}$ & $656.53 \pm 2.78^{b}$ & $26.34 \pm 0.80^{\mathrm{b}}$ & $35.76 \pm 1.38^{b}$ & $11.04 \pm 0.38^{b}$ \\
\hline 15 days & $308.01 \pm 2.28^{\mathrm{a}}$ & $204.39 \pm 1.75^{\mathrm{a}}$ & $133.04 \pm 1.96^{\mathrm{a}}$ & $675.95 \pm 1.64^{\mathrm{a}}$ & $41.24 \pm 1.24^{\mathrm{a}}$ & $57.50 \pm 1.56^{\mathrm{a}}$ & $16.73 \pm 0.36^{\mathrm{a}}$ \\
\hline \multicolumn{8}{|l|}{ A. digitata } \\
\hline Raw & $111.01 \pm 0.49^{\mathrm{d}}$ & $59.14 \pm 0.26^{\mathrm{d}}$ & $170.38 \pm 0.00^{\mathrm{d}}$ & $415.39 \pm 1.84^{\mathrm{d}}$ & $23.77 \pm 0.10^{\mathrm{d}}$ & $8.30 \pm 0.03^{\mathrm{d}}$ & $5.06 \pm 0.02^{\mathrm{d}}$ \\
\hline 5 days & $144.49 \pm 0.78^{c}$ & $77.09 \pm 0.21^{\mathrm{c}}$ & $221.33 \pm 0.62^{\mathrm{c}}$ & $539.52 \pm 0.56^{\mathrm{c}}$ & $31.23 \pm 0.06^{\mathrm{c}}$ & $15.08 \pm 0.14^{\mathrm{c}}$ & $6.71 \pm 0.00^{c}$ \\
\hline 10 days & $178.63 \pm 1.55^{b}$ & $95.93 \pm 0.36^{\mathrm{b}}$ & $253.27 \pm 0.07^{b}$ & $665.83 \pm 1.66^{\mathrm{b}}$ & $38.83 \pm 0.11^{\mathrm{b}}$ & $20.44 \pm 0.30^{\mathrm{b}}$ & $8.50 \pm 0.02^{b}$ \\
\hline 15 days & $203.59 \pm 2.50^{\mathrm{a}}$ & $109.77 \pm 1.96^{\mathrm{a}}$ & $271.82 \pm 6.76^{\mathrm{a}}$ & $759.45 \pm 0.74^{\mathrm{a}}$ & $44.41 \pm 0.57^{\mathrm{a}}$ & $24.23 \pm 0.66^{\mathrm{a}}$ & $10.17 \pm 0.06^{\mathrm{a}}$ \\
\hline \multicolumn{8}{|l|}{ V. unguiculata } \\
\hline Raw & $87.73 \pm 0.11^{\mathrm{d}}$ & $63.13 \pm 0.03^{\mathrm{d}}$ & $61.68 \pm 0.00^{\mathrm{d}}$ & $143.33 \pm 0.18^{\mathrm{d}}$ & $18.25 \pm 0.02^{\mathrm{c}}$ & $6.65 \pm 0.00^{\mathrm{d}}$ & $6.92 \pm 0.00^{\mathrm{d}}$ \\
\hline 5 days & $119.49 \pm 0.64^{c}$ & $93.18 \pm 0.77^{\mathrm{c}}$ & $84.56 \pm 0.68^{c}$ & $195.12 \pm 1.67^{\mathrm{c}}$ & $25.08 \pm 2.07^{\mathrm{b}}$ & $7.91 \pm 1.26^{\mathrm{c}}$ & $11.26 \pm 0.45^{\mathrm{c}}$ \\
\hline 10 days & $129.58 \pm 0.36^{b}$ & $101.45 \pm 0.67^{b}$ & $91.12 \pm 1.36^{\mathrm{b}}$ & $211.21 \pm 0.67^{b}$ & $27.54 \pm 1.58^{\mathrm{b}}$ & $9.80 \pm 0.44^{\mathrm{b}}$ & $12.38 \pm 0.25^{b}$ \\
\hline 15 days & $144.71 \pm 0.38^{a}$ & $113.58 \pm 0.49^{\mathrm{a}}$ & $100.77 \pm 1.05^{\mathrm{a}}$ & $236.39 \pm 0.47^{\mathrm{a}}$ & $31.26 \pm 0.87^{\mathrm{a}}$ & $10.81 \pm 0.20^{\mathrm{a}}$ & $14.57 \pm 0.13^{\mathrm{a}}$ \\
\hline \multicolumn{8}{|c|}{ 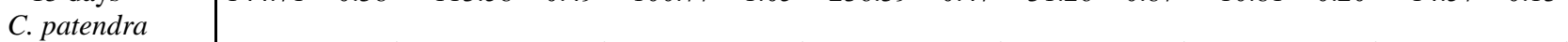 } \\
\hline Raw & $294.62 \pm 0.16^{\mathrm{d}}$ & $228.58 \pm 0.13^{\mathrm{d}}$ & $168.69 \pm 0.62^{\mathrm{d}}$ & $468.54 \pm 0.26^{\mathrm{d}}$ & $64.96 \pm 0.03^{\mathrm{d}}$ & $12.61 \pm 0.00^{\mathrm{d}}$ & $10.54 \pm 0.00^{\mathrm{d}}$ \\
\hline 5 days & $308.24 \pm 1.24^{\mathrm{c}}$ & $239.78 \pm 1.02^{\mathrm{c}}$ & $177.00 \pm 2.63^{c}$ & $489.95 \pm 2.59^{c}$ & $68.08 \pm 1.63^{\mathrm{c}}$ & $18.39 \pm 0.59^{\mathrm{c}}$ & $11.08 \pm 0.01^{\mathrm{c}}$ \\
\hline 10 days & $335.31 \pm 0.81^{b}$ & $260.78 \pm 0.88^{b}$ & $192.49 \pm 1.79^{b}$ & $533.06 \pm 2.23^{b}$ & $71.15 \pm 0.28^{b}$ & $20.60 \pm 0.35^{b}$ & $12.92 \pm 0.08^{b}$ \\
\hline 15 days & $408.09 \pm 0.92^{\mathrm{a}}$ & $317.23 \pm 2.01^{\mathrm{a}}$ & $234.38 \pm 2.79^{\mathrm{a}}$ & $648.85 \pm 2.59^{\mathrm{a}}$ & $92.03 \pm 2.61^{\mathrm{a}}$ & $25.43 \pm 0.75^{\mathrm{a}}$ & $14.92 \pm 0.04^{\mathrm{a}}$ \\
\hline
\end{tabular}
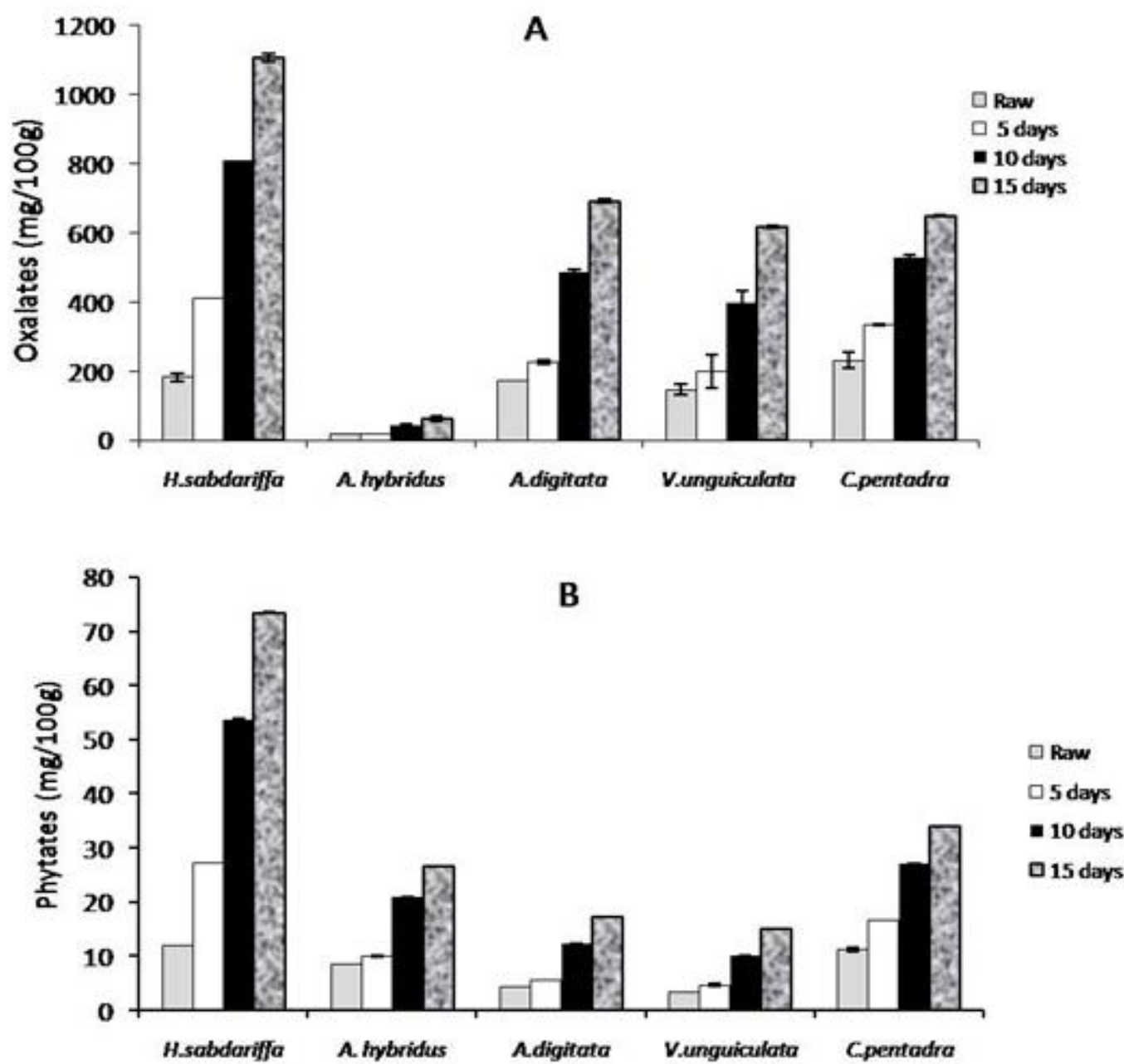

Figure 1 Effect of shadow drying on oxalates (A) and phytates (B) contents of leafy vegetables consumed in Northern Côte d'Ivoire 
Table 3 Anti-nutritional factors/mineral ratios of shade dried leafy vegetables consumed in Northern Côte d'Ivoire

\begin{tabular}{|c|c|c|c|}
\hline Leafy vegetables & Phytates/Ca & Phytates/Fe & Oxalates/Ca \\
\hline \multicolumn{4}{|l|}{ H.sabdariffa } \\
\hline Raw & 0.21 & 0.85 & 3.26 \\
\hline 5 days & 0.32 & 0.84 & 4.89 \\
\hline 10 days & 0.33 & 0.84 & 5.01 \\
\hline 15 days & 0.34 & 0.83 & 5.06 \\
\hline \multicolumn{4}{|l|}{ A.hybridus } \\
\hline Raw & 0.03 & 0.16 & 0.07 \\
\hline 5 days & 0.03 & 0.41 & 0.07 \\
\hline 10 days & 0.03 & 0.41 & 0.11 \\
\hline 15 days & 0.03 & 0.40 & 0.08 \\
\hline \multicolumn{4}{|l|}{ A.digitata } \\
\hline Raw & 0.04 & 0.21 & 1.57 \\
\hline 5 days & 0.04 & 0.18 & 1.57 \\
\hline 10 days & 0.04 & 0.19 & 1.82 \\
\hline 15 days & 0.04 & 0.19 & 1.63 \\
\hline \multicolumn{4}{|l|}{ V.unguiculata } \\
\hline Raw & 0.04 & 0.19 & 1.66 \\
\hline 5 days & 0.04 & 0.19 & 1.66 \\
\hline 10 days & 0.04 & 0.20 & 1.85 \\
\hline 15 days & 0.04 & 0.20 & 1.74 \\
\hline \multicolumn{4}{|l|}{ C.patendra } \\
\hline Raw & 0.04 & 0.17 & 0.78 \\
\hline 5 days & 0.04 & 0.18 & 0.59 \\
\hline 10 days & 0.04 & 0.19 & 0.78 \\
\hline 15 days & 0.04 & 0.18 & 0.79 \\
\hline
\end{tabular}
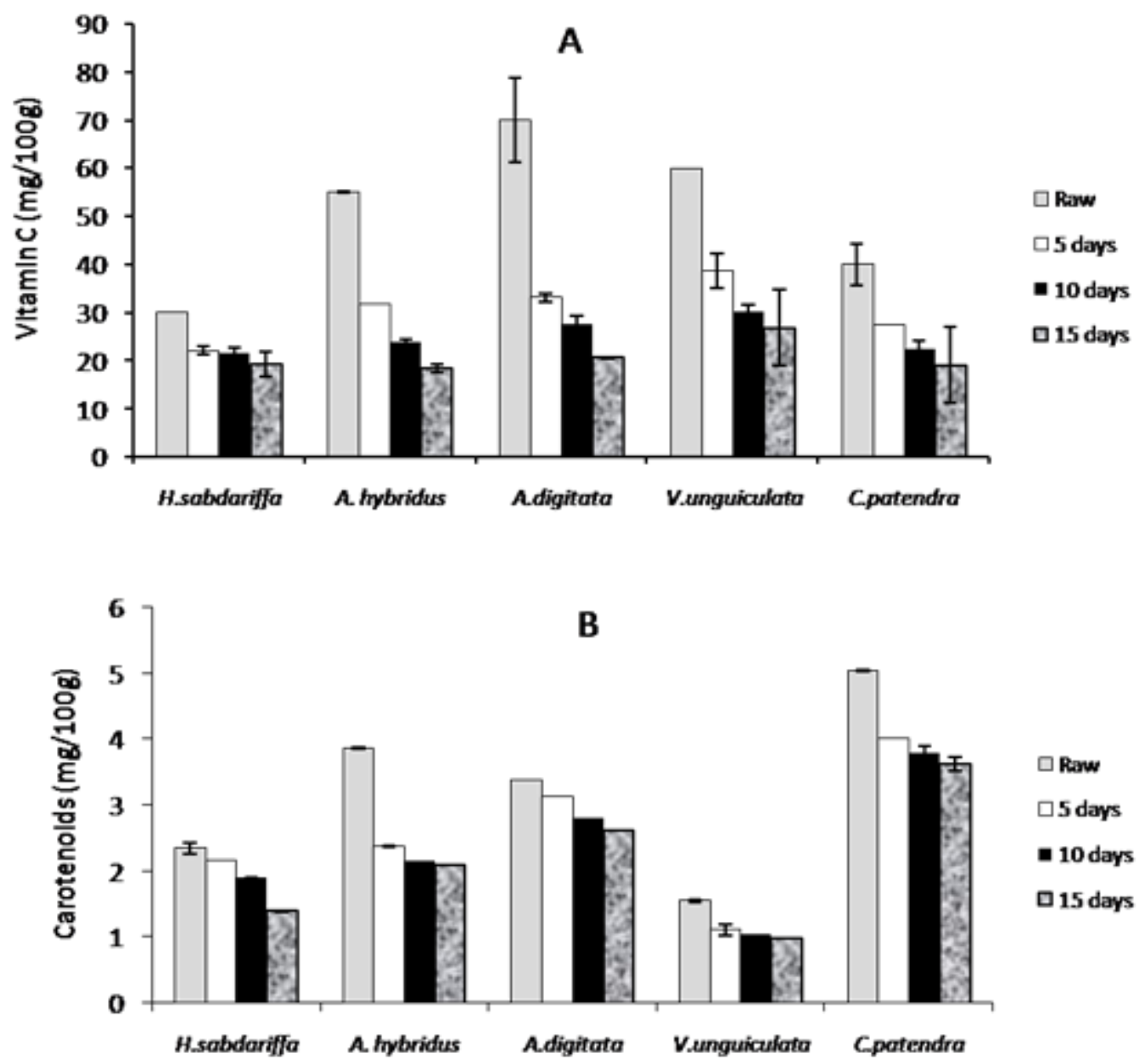

Figure 2 Effect of shadow drying on vitamin C (A) and carotenoids (B) contents of leafy vegetables consumed in Northern Côte d'Ivoire 


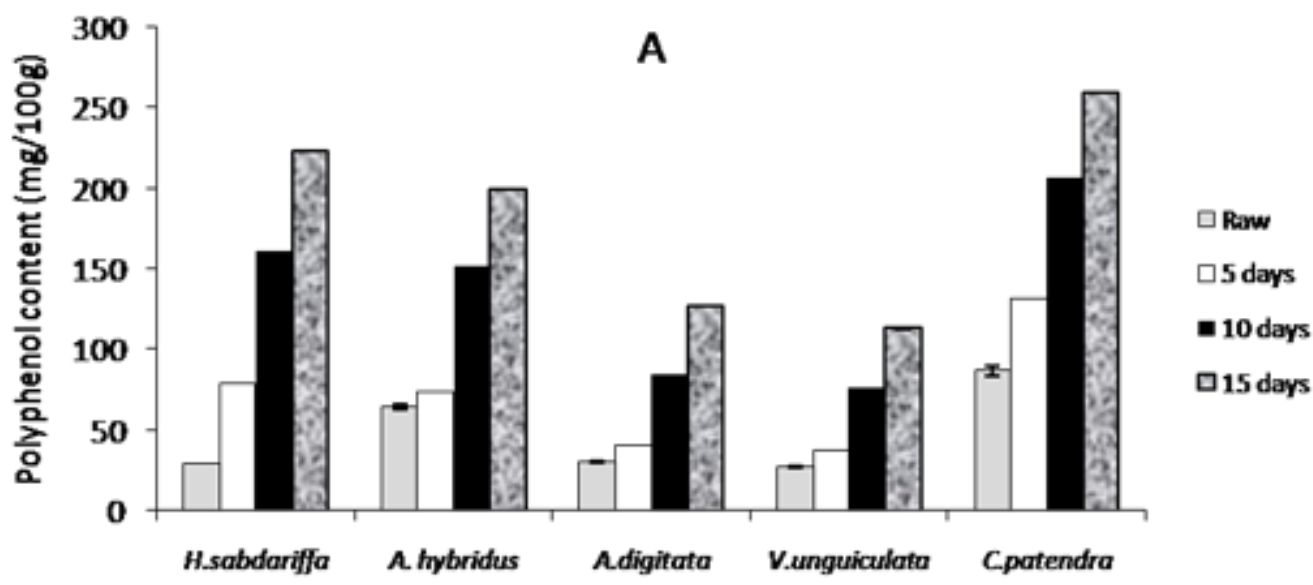

B

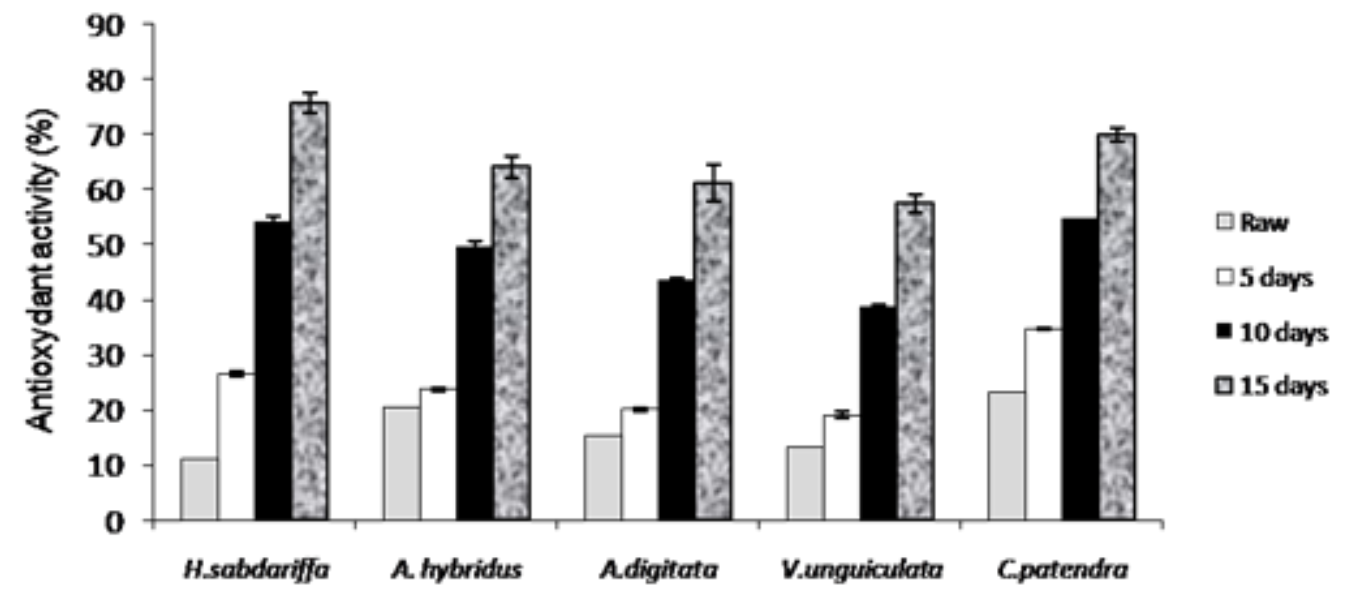

Figure 3 Effect of shadow drying on polyphenols contents (A) and antioxidant activity (B) contents of leafy vegetables consumed in Northern Côte d'Ivoire

Most common antioxidants in vegetables and spices are vitamin $\mathrm{C}$, E, phenolic compounds and carotenoids (Priecina and Karklina, 2014). The contents of vitamin C and carotenoids in the shade dried leafy vegetables are shown in Figure 2. In all the samples, vitamin $\mathrm{C}$ and carotenoids contents were depleted during shadow drying. Indeed losses of these antioxidants components were $35.52-70.50 \%$ and $22.82-45.63 \%$, respectively after 15 days of shadow drying. Vitamin $\mathrm{C}$ and carotenoids losses were directly dependent on the method of drying leafy vegetables. Indeed, shadow drying generally lead to lower vitamin $\mathrm{C}$ and carotenoids contents due to oxidation phenomenon (Aletor and Adeogun, 1995). In addition, the registered losses in vitamin $\mathrm{C}$ and carotenoids were higher than those $(8-26 \%)$ of pretreated (blanching and sulphiting) and dried leaves. Therefore, this justifies the fact that several authors have applied different pretreatments before solar and sun-drying processes in order to improve the quality and nutritional parameters of dried products (Negi and Roy, 2001). The phenolic contents of the samples increased during shadow drying as depicted in Figure 3. The values were in the range of
113.17-259.78 mg/100 $\mathrm{g}$ at 15 days of drying. These values were 3 to 8 -fold higher than those $(27.15-86.61$ $\mathrm{mg} / 100 \mathrm{~g}$ ) of the fresh ones. Increase in phenolic compounds may be due to concentration effect of drying on nutrients. Phenolic components are secondary metabolites synthesized by plants, both during normal development and in response to stress conditions (infection, wounding, UV radiation and others) (Nackz and Shahidi, 2006). They also have antioxidant properties that enable them to quench free radicals which lead to beneficial effect on human health by reducing the occurrence of coronary heart diseases (John et al., 2005). Furthermore, increasing in phenolic contents caused also the increase of antioxidant activity (Figure 3 ) because there is a direct correlation between the concentration of antioxidant compounds and the antioxidant activity (Lan, 2007). Antioxidant activity ranged from $57.45 \pm 0.00 \%$ to $75.55 \pm 0.00 \%$ after 15 days of shadow drying. Thus, this increase in phenolics contents and antioxidant activity could be explored for nutraceutical recipes confection including shadow dried leaf powder. 


\section{Conclusion}

The results obtained in this study showed that shadow drying had concentration effect on the nutrients contents of the studied leafy vegetables (protein, ash, fat, crude fiber and carbohydrates). Shadow drying produced leafy vegetables with lower moisture content and the amounts of vitamins and phenolics could be of value especially in areas that poor populations do not have "alternative sources of micronutrients." Therefore shadow drying should be encouraged as a way of ensuring all year round supply of vegetables and micronutrients to all risk groups. This food based approach may serve as a means of reducing "hidden hunger" in developing countries.

\section{References}

Adepoju OT, Oyewole OE. 2008. Nutritional importance and micronutrient potential of two non-conventional indigenous green leafy vegetables from Nigeria. Agric J, 3 (5): 365-368.

Aletor VA, Adeogun OA. 1995. Nutrient and anti-nutrient components of some tropical leafy vegetables. Food Chem, 53: 375-379.

AOAC. 1990. Official methods of analysis. Association of Official Analytical Chemists Ed., Washington DC, 684 p.

CEAEQ. 2013. Mineral determination. Argon plasma spectrometry method, MA 200 - Met 1.2, Rev 4. Quebec, 24 p.

Choi CW, Kim SC, Hwang SS, Choi BK, Ahn HJ, Lee MZ, Park SH, Kim SK. 2002. Antioxydant activity and free radical scavenging capacity between Korean medicinal plant and flavonoids by assay guided comparison. Plant Sci, 163: 11611168.

Chou SK, Chua KJ. 2001. New hybrid technologies for heat sensitive foodstuffs. Trends in Food Science and Technology: A Handbook of vegetables and vegetable processing. Academic Press, pp. 185 - 195.

Day RA, Underwood AL. 1986. Quantitative analysis. 5th ed. Prentice Hall. 701 p.

Dupriez H, Coener P. 1992. African garden and orchards growing vegetables and fruits. Macmillan Press Limited, London, pp. 3546.

Ejoh RA, Nkonga DV, Inocent G, Moses MC. 2007. Nutritional Components of Some Non-Conventional Leafy Vegetables Consumed in Cameroon. Pak J Nutr, 6 (6): 712-717.

Elegbede JA. 1998. Legumes. Nutritional quality of plant foods. In: Post Harvest Research Unit. Osagie AU, Eka, QU (Eds).

Fakeye IO. 2009. Nigerian Leafy Vegetable. Nig J Food Sci, 1: 5559.

FAO. 2002. Food energy-methods of analysis and conversion factors. FAO Ed, Rome, $97 \mathrm{p}$.

FAO. 2004. Human vitamin and mineral requirements. FAO. Ed. $361 \mathrm{p}$.

Florkowski JW, Robert LS, Bernhard B, Stanley EP. 2009. Postharvest Handling: A Systems Approach, Second Edition. Elsevier Inc. Academic Press.

Fondio L, Kouamé C, N'zi JC, Mahyao A, Agbo E, Djidji AH. 2007. Survey of indigenous leafy vegetable in the urban and peri-urban areas of Côte d'Ivoire. Acta Hort, 752: 287-289.

Hassan SW, Umar RA, Maishanu HM, Matazu IK, Faruk UZ, Sani AA. 2007. The effects of drying method on the nutrients and non-nutrients composition of leaves of Gynandropsis gynandra (Capparaceae). Asian J. Biochem, 5: 349-353.

Ifon ET, Bassir O, Latunde-Dada GO. 2009. The nutritive value of some Nigerian leafy vegetables. Part 1 , Vitamin and mineral content. Food Chem, 3: 267-350.

John S, Haseeb N, Joseph P, Gauri M, Yukio K, Yueming J. 2005. Extraction of polyphenolics from plant material for function foods-engineering and technology. Food Rev. Int, 21: 139-166.
Joshi P, Mehta D. 2010. Effect of dehydration on the nutritive value of drumstick leaves. J. Metabol Syst Biol, 1: 5-9.

Kolawale OM, Kayode RM, Aina J. 2010. Effect of solar drying on the proximate and microbial composition of Abelmoschuus esculentus. J Agric Sci, 2: 214 - 224.

Komal M, Kaur A. 1992. Reviews: Dietary Fibre. Dieticians, Adipostat Clinic, Lady Ratan Tata Medical Centre, Bombay.

Kyureghian G, Stratton J, Bianchini A, Albrecht J. 2010. Nutritional comparison of frozen and non-frozen fruits and vegetables: Literature review. The food processing center, University of Nebraska-Lincoln, 48 p.

Lakshmi B, Vimla V. 2000. Nutritive value of dehydrated green leafy powders. J Food Sci Technol, 37(5): 465-471.

Lan W. 2007. Effect of chlorogenic acid on antioxidant activity of Flos lanicerae extracts. J. Zhejiang Univ Sci Biol, 8: 673-679.

Latta M, Eskin M. 1980. A simple method for phytate determination. J Agric Food Chem, 28: 1313-1315.

Medeiros L, Remley D. 2009. Drying fruits and vegetables. Ohio State University Extension; and, Extension. Ohio State.

Morris A, Barnett A. and Burrows O. 2004. Effect of processing on nutrient content of foods: A handbook of vegetables and vegetable processing. Asian J Biochem, 37 (3): 160 - 164.

Naczk M, Shahidi E. 2006. Phenolics in cereals, fruits and vegetables: Occurrence, extraction and analysis. J Pharm Biomed Anal, 41: 1523-1542.

Negi PS, Roy SK. 2001. Effect of drying conditions on quality of green leaves during long term storage. Food Res Int, 34: 283287.

Oguche HE. 2011. Effect of drying methods on chemical composition of spinach "Aieifo" (Amaranthus aquatica) and pumpkin leaf (Telfairia occidentalis) and their soup meals. Pak J Nutr, 10: 1061-1065.

Onwuka GI, Nwabara CC, Nwokedi PM, Echendu CA, Asumugha U, Igboekwe MU. 2002. Comparative studies of the efficacy of sun drying, solar dryer and hot air oven in the preservation of tomatoes, okra, pepper and onion. Nig Food J, 20: $10-14$.

Oselebe HO, Nnamani CV, Okporie EO. 2013. Ethnobotanical survey of underutilized crops and spices of some local communities in Nigeria: potentials for improved nutrition, food security and poverty reduction. Iosr J Pharm, 3: 2250-3013.

Oulai PD, Zoué LT, Mégnanou RM, Doué RM, Niamké SL. 2014. Proximate composition and nutritive value of leafy vegetables consumed in Northern Côte d'Ivoire. Eur Sci J, 10: 212-227.

Pongracz G, Weiser H, Matzinger D. 1971. TocopherolsAntioxydant. Fat Sci Technol, 97: 90-104.

Prabhu S, Barrett D. 2009. Effects of storage condition and domestic cooking on the quality and nutrient content of African leafy vegetables (Cassia tora and Corchorus tridens). J Sci Food Agric, 89: 1709-1721.

Priecina L, Karklina D. 2014. Natural antioxidant changes in fresh and dried spices and vegetables. Int J Biol Vet Agric Food Eng, 8: $480-484$.

Rodriguez-Amaya DB. 2001. A guide to carotenoids analysis in foods, ILSI Press, Washington DC, $64 \mathrm{p}$.

Rossello C, Berna A, Mulet A. 2000. Solar drying of fruits in a Mediterranean climate. Drying Technol, 8 (2): 305 - 321.

Singleton VL, Orthofer R, Lamuela-Raventos RM. 1999. Analysis of total phenols and other oxydant substrates and antioxydants by means of Folin-ciocalteu reagent. Methods Enzymol, 299: 152-178.

Soetan KO, Olaiya CO, Oyewole OE. 2010. The importance of mineral elements for humans, domestic animals and plants: A review. Afr J Food Sci, 4: 200-222.

Subhash B, Neeha VS. 2014. Dehydration of green leafy vegetable: Review. Int J Innov Res. Technol, 1: 58-64.

Vanderhulst P, Lanser H, Bergmeyer P, Albers R. 1990. Solar energy: small scale applications in developing countries. Int. Food J, 8: 138-142. 